\title{
EFFECT OF SOME BIO AND CHEMICAL FERTILIZERS ON GROWTH AND CHEMICAL COMPOSITION OF Pinus halepensis, MIL L. SEEDLINGS
}

HESHAM A. GHARIB and HANAN M. A. YOUSSEF

Timber trees and Forestry Res. Dep., * Floriculture and Landscape Design Res. Dep., Hort. Res. Ins., ARC, Giza, Egypt. (Manuscript received 22 April 2013)

\begin{abstract}
An attendance study was approved to conclude the influence of different fertilization types and levels to increment Pinus halepensis seedling quality and enhance growth rats under nursery conditions. Seedlings of pinus (one-year-old cultivated on $14 \mathrm{~cm}$ black polyethylene bag filled with a mixture of sand, loam $1: 1, \mathrm{v} . / \mathrm{v}$.) were carried out during two successive seasons (2011 and 2012) at the nursery of Timber Trees and Forestry Res. Dept., Hort. Res. Inst., Giza, Egypt. In derail, organic fertilizers "Biogien" (3.00-6.00 $\mathrm{g} / \mathrm{bag}$ ) and "Rhizobacterien" (3.00-6.00 g/bag) as bio-fertilizer addition to mineral "NPK" (1:1:1) at stages of $(1.00,2.00$ and $4.00 \mathrm{~g} / \mathrm{bag})$ and "Vive Rose" as a foliar spray (1.00-2.00 g/l) were used in derail. Fertilizer applications were used to investigate the effects on growth parameters and the chemical composition of $P$. halepensis. The data revealed seedlings treated with "Biogien" at $6.00 \mathrm{~g} / \mathrm{seedling}$ had the best significant seedling quality (SQ) and chemical composition during two seasons. In this view, "Vive Rose" as a foliar application at $(2.00 \mathrm{~g} / \mathrm{l})$ had a significant increment in stem height, stem diameter, branch number, root length, fresh and dry weights of aerial parts (stems and leaves), fresh and dry weights of roots, the relative growth rate of height (RGRH), the relative growth rate of length (RGRD), total dry biomass percentage, and nutrient uptake compared to control. In the meantime, "Rhizobacterien" at $6.00 \mathrm{~g} / \mathrm{sedling}$ significantly enhanced root length and leaf content of chlorophyll b, carotenoids, $\mathrm{N}$, and $\mathrm{K}$ percentage compared to mineral fertilizer. Using "Biogien" at $6.00 \mathrm{~g} / \mathrm{bag}$ for pine seedlings recorded the strongest seedlings, as well as reduced time in the nursery to minimize seedling production costs and improve our environment.
\end{abstract}

Keywords: Bio-fertilizer "Biogien" -" Rhizobacterien" Foliar-fertilizer "Vive Rose" - NPK- Fertilization Vegetative growth -Chemical composition - Pinus halepensis $\mathrm{L}$. 


\section{INTRODUCTION}

Pinus halepensis, Mill. ( $P$. alepensis, Poir.) Fam. Pinaceae, normally recognized as, The Aleppo Pine, is a pine resident of the Mediterranean area. $P$. halepensis is a intermediate tree, over than $15.00 \mathrm{~m}$ in height, with stem diameter up to $60.00 \mathrm{~cm}$. The bark is nearly orange-reddish, thick fissured at bottom of the trunk's tree furthermore slim and flaky in the top crown. The leaves are needles shape and slender, 6-12 cm in length, definitely yellowish-green, and pairs. The cones are thin conical, up $5.00 \mathrm{~cm}$ tall and over $2.00 \mathrm{~cm}$ wide at the bottom while closed, green at primary, maturing shiny almost reddish-brown after 24 months. They open gradually after a few years, a development almost rapidly if it showed then to thermal such as the forest's fires. The cones immediately open to discharge the seeds to separate. The seeds length are nearly $0.50 \mathrm{~cm}$, with a $2.00 \mathrm{~cm}$ wing, and are air-dispersed. Bailey, (1976).

Pine trees have a significant impact on the economy in timber prices, pulp manufacturing, watershed management, fuel, and amenities. Fady, (2012). Trees have a very significant role in the economy and natural science. Barbero et al., (1998), it has used soil protection and windbreaks to enhance water penetration on mountainous slopes and to avoid soil erosion on slopes Farjon, (2010). Seeds of $P$. halepensis are made into pastry in North Africa Maestre and Cortina, (2004).

The studies in this side suggest that growth of root promotion is manipulated by growth environmental and that IAA applications and root respiration rates are two composition mechanisms connected with rhizobacteria activity and root promotion. Barriuso, et al. (2008) this study observed that the possible of PGPR due to increment strength of forest trees. Furthermore, the definitely among the mycorrhiza addition to the bacteria inoculated that the seedling choices engage a possible biotechnological manufacture of value-added fungi of $P$. pinea. Bio-fertilization is a popular method of fertilizing seedlings. Azotobacter chroococcum plays a key role in nitrogen cycle fixation, producing vitamins such as thiamine and riboflavin, Revillas et al., (2000) as well as plant hormones such as IAA, GA, and cytokinins Van Loon, (2007). Bhattacharyya, (2012) obligated that Azospirillum brasilense had a novel nitrogenfixing bacteria that promote several aspects of seedling development. Enebak et al. (1998) found that applying plant growth promoting rhizobacteria (PGPR) to Pinus taeda seedlings reduced damping-off and incremented growth. Inoculation using Bacillus megaterium, which is a phosphorus dissolvent, enhances phosphate accessibility in the root rhizosphere Rodriguez and Fraga, (1999). Bacteria such as Pseudomonas spp., Bacillus spp., Azotobacter spp., and Azospirillum spp. Saharan and Nehra, (2011). When $P$. pinea seedlings are inoculated with PGPR, the seedlings develop faster. All criteria were shown to be improved when bio-fertilizer types were used Probanza et al., (2002), Ramos et al., (2006) and Jaiti, (2007). The use of diverse bio-fertilizers that are more capable than $\mathrm{N}, \mathrm{P}$, and $\mathrm{K}$ in plant contents $\mathrm{Wu}$ et al., (2005), as well as the content of chlorophyll a, b, carotenoids, and carbohydrates Wu et al., (2005). Watfa, (2009). Dominguez, et al., (2012) found that several rhizobacteria were competent to instrument an organization moreover performance of ecto-mycorrhiza symbiosis. In this survey, trees of $P$. halepensis were immediately inoculated by the mycorrhiza Tuber melanosporum plus the rhizobacteria. A previous five months nearly later from inoculation, we assessed the growth parameters of seedling, mycorrhiza colonies applications, elements absorption plus elements contents ( $\mathrm{Ca}, \mathrm{N}, \mathrm{P}, \mathrm{K}, \mathrm{Fe}$ and $\mathrm{Mg}$ ) in roots and aerial parts of the seedlings. Consequently, experiments designed to estimate the growth of root potentials. None of the processes changed the parameters of water or the root's growth potentials. The inoculations enhanced the growth and element absorbent of the root seedlings, while the combination of pine and mycorrhiza rarely led to a significant enhancement over the encouraging effects of an uncomplicated inoculation of mycorrhiza though the 
adding of pine performed twice the rate of the mycorrhiza. These effects might promise improvement in the cultivation of truffles.

There for lately farmers favored using the bio-fertilizers to save the environment. So this examination aims to establish the best type and suitable amount of some bio-fertilizer types "Biogien" or "Rizobacterien" or chemical fertilization (NPK "as soil drench" and Vive Rose as a foliar spray) to recognize the high quality growth of $P$. halepensis seedlings.

\section{MATERIALS AND METHODS}

At the open field in the Woody Trees and Forestry Nursery of the Experimental Farm of Hort. Res. Inst., Giza, Egypt during the 2011 and 2012 seasons, this investigation was performed to study the effects of either bio-fertilizer "Biogien" or "Rizobacterien" or "chemical fertilization" (NPK "as soil drench" and "Vive Rose" as a foliar spray) at various rates on the growth and chemical composition of $P$. halepensis seedlings. One-year-old transplants of $P$. halepensis are growing in $14 \mathrm{~cm}$ black polyethylene bags "one plant per bag" filled with about $700 \mathrm{~g}$ of an equal mixture of sand and loam (1:1 by volume). The physical and chemical properties of the used sand and loam soil are shown in Table (a), which were analyzed according to A.O.A.C. (1990).

Table a. Some physical and chemical properties of the used mixture in the two seasons (2011and 2012).

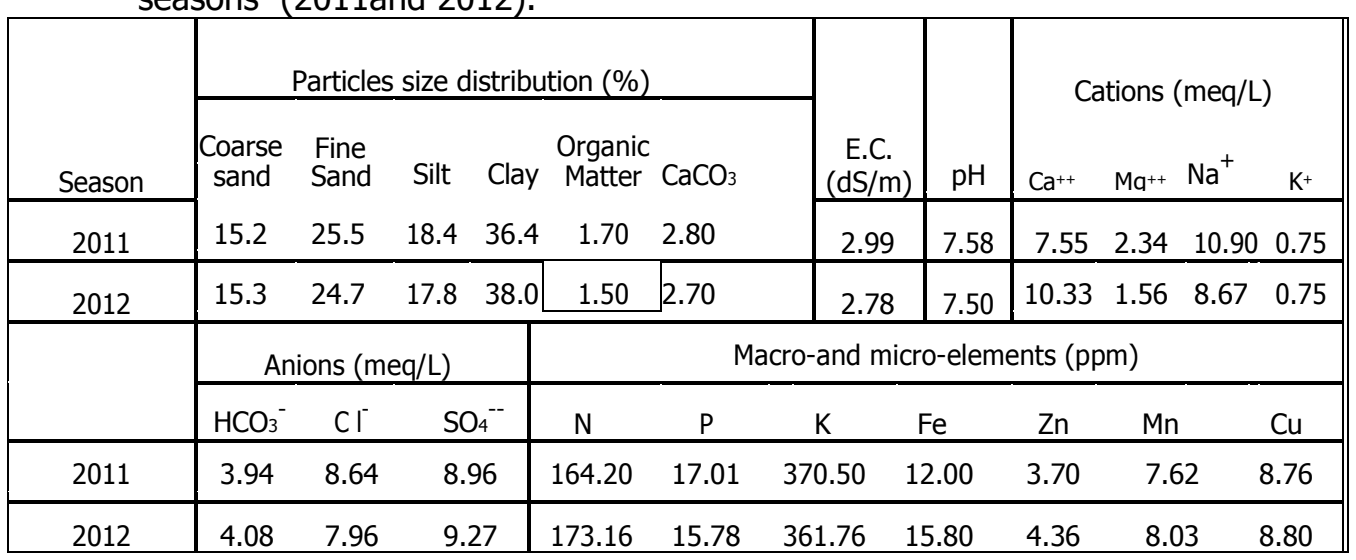

\section{Fertilizer treatment composition:}

\section{1- Biofertilizer as follows:}

a- "Biogien", a commercial product containing a specific clone of Azotobacter chroococcum bacteria, conc. $10^{6}$ cells $/ \mathrm{ml}$.

b- "Rhizobacterien", a commercial product containing a specific clone of Rhizobium $s p$. bacteria, conc. $10^{7-1} 10^{8} \mathrm{cells} / \mathrm{ml}$.

2- A mixture of chemical fertilization NPK (1:1:1) was added as soil drench (at the levels of $1.00,2.00 \mathrm{~g} /$ bags $)$. Fertilizers were used for ammonium sulphate $(20.5 \% \mathrm{~N})$, calcium super phosphate $\left(15.5 \% \mathrm{P}_{2} \mathrm{O}_{5}\right)$, and potassium sulphate $\left(48.5 \% \mathrm{~K}_{2} \mathrm{O}\right)$.

3- Liquid fertilizer Tab. (b) clears the content of "Vive Rose" fertilizer according to the company's produced "UAD" union for Agric. development w/w. was sprayed on the foliage till run-off at the levels of 1.00 and $2.00 \mathrm{~g} / \mathrm{l}$. of water. 
Table b. The content's of "Vive Rose" fertilizer

\begin{tabular}{|c|c|c|c|c|c|c|c|c|c|c|}
\hline $\mathrm{N} \%$ & $\begin{array}{c}\mathrm{P} \% \\
\text { "P2 } \mathrm{O}_{5} "\end{array}$ & $\begin{array}{c}\mathrm{K} \% \\
\text { " } \mathrm{K}_{2} \mathrm{O} " \\
\end{array}$ & $\mathrm{Fe} \%$ & $\mathrm{Zn} \%$ & $\mathrm{Mn} \%$ & $\mathrm{Cu} \%$ & $\mathrm{Mg} \%$ & $\mathrm{Ml} \%$ & $\begin{array}{r}\text { Citric } \\
\text { acid\% }\end{array}$ & sucrose $\%$ \\
\hline 22.00 & 5.00 & 11.00 & 0.05 & 0.07 & 0.24 & 0.05 & 0.3 & 0.5 & 0.002 & 0.07 \\
\hline
\end{tabular}

All seedlings under the various treatments received the usual agricultural practices such as weeding, etc. whenever needed. Data was also collected at the end of each season. The first season began on $1 / 3 / 2010$ and ended $1 / 5 / 2011$. Treatments for the second season, which began on $1 / 3 / 2011$ and ended $1 / 5 / 2012$, treatments as follows: 1 - Seedlings without treatment as control.

2- Individuals treated with "Biogien" $2.00 \mathrm{~g} /$ seedling at ( $1^{\text {st }}$ March, $1^{\text {st }} \mathrm{April}$, and $1^{\text {st }}$ May) for $6.00 \mathrm{~g} / \mathrm{seedling}$ during season.

3- Individuals treated with "Biogien" $1.00 \mathrm{~g} /$ seedling at ( $1^{\mathrm{st}}$ March, $1^{\text {st }} \mathrm{April}$, and $1^{\text {st }}$ May) for $3.00 \mathrm{~g} /$ seedling during season.

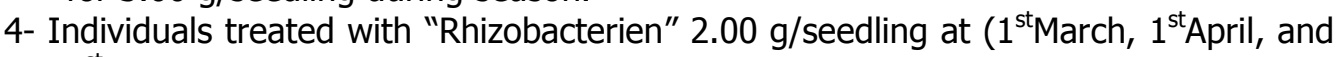
$1^{\text {st }}$ May) for $6.00 \mathrm{~g} /$ seedling during season.

5- Individuals treated with "Rhizobacterien" $1.00 \mathrm{~g} /$ seedling at $\left(1^{\text {st }} M a r c h, 1^{\text {st }} A p r i l\right.$, and

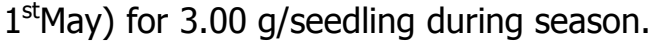

6- Individuals treated with "Vive Rose" as a foliar spray $0.66 \mathrm{~g} / \mathrm{l}$ at $\left(1^{\mathrm{st}}\right.$ March, $1^{\text {st }} \mathrm{April}$, and $1^{\text {st } M a y) ~ f o r ~} 2.00 \mathrm{~g} / \mathrm{l}$ during season.

7- Individuals treated with "Vive Rose" as a foliar spray $0.33 \mathrm{~g} / \mathrm{l}$ at $\left(1^{\text {st }}\right.$ March, $1^{\text {st }}$ April, and $1^{\text {st } M a y) ~ f o r ~} 1.00 \mathrm{~g} / \mathrm{l}$ during season.

8- Individuals treated with "NPK" $\mathrm{g} /$ seedling $1.33 \mathrm{~g} /$ seedling at $\left(1^{\text {st }} M a r c h, 1^{\text {st }} A p r i l\right.$, and $1^{\text {st }}$ May) for $4.00 \mathrm{~g} /$ seedling during season.

9- Individuals treated with "NPK" g/seedling $0.66 \mathrm{~g} /$ seedling at $\left(1^{\text {st }} M a r c h, 1^{\text {st }} A p r i l\right.$, and $1^{\text {st }}$ May) for $2.00 \mathrm{~g} /$ seedling during season.

10- Individuals treated with "NPK" $\mathrm{g} /$ seedling $0.33 \mathrm{~g} /$ seedling at $\left(1^{\text {st }}\right.$ March, $1^{\text {st }} A p r i l$, and $1^{\text {st }}$ May) for $1.00 \mathrm{~g} /$ seedling during season.

\section{Seedlings growth parameters:}

seedling height $(\mathrm{cm})$, stem diameter at soil surface $(\mathrm{cm})$, number of branches/plant, root length/plant $(\mathrm{cm})$, fresh and dry weights of aerial parts (stems and leaves), fresh and dry weights of roots (g)Survival \% , (SQ) (Equation 1) was assessed based on Thompson (1985). The relative growth rates of height (RGRH, mm cm_1 d_1) and relative growth rate of diameter, (RGRD, $\mu \mathrm{m} m \mathrm{~mm} 1$ d_1) were calculated by using equations 2and 3 from $1^{\text {st }}$ Feb. to $1^{\text {st }}$ May according to Ostos et al. (2008).

\section{SQ $=H$ (plant height) / D (stem diameter) \\ RGRH=Ln H2-Ln H1 /t2-t1 \\ RGRD=Ln D2-Ln D1/t2-t1 measurements, respectively, D2 and D1 stem diameter $(\mathrm{mm})$ in the last and first measurements, respectively, t2-t1 (days) are the last and first sampling dates, respectively, and $L n$ is the natural logarithm.

The seedling quality index (QI) Dickson et al., (1960), total dry biomass increment percent (Dhindwal et al., 1991,; Iqbal et al., 2007), and nutrient uptake (g/seedling) Jackson, (1973) were calculated using formulas 4-5 and 6a, respectively. 
The seedling quality index $(\mathrm{QI})=$ Total seedling dry weight(g) / height $(\mathbf{c m}) /$ diameter $(\mathbf{m m})+$ shoot dry weight $(\mathrm{g}) /$ root dry weight $(\mathbf{g})$

Total dry biomass increment (\%) =Total dry weight of the treatment - Total dry

weight of the control treatment / dry weight of the control treatment*100

Nutrient uptake $(\mathrm{g} /$ seedling $)=$ Nutrient content $(\%) *$ dry matter $(\mathrm{g}) / 100$

seedling chemical analysis:

- In fresh leaf samples taken from the middle parts of the plants, photosynthetic pigments (chlorophyll a, b, and carotenoids, mg/g F.W.) were determined according to Moran (1982).

- Total indoles and total soluble phenols were determined colourimetrically by using Folin Ciocaltea reagent A.O.A.C.(1990).

- In dry aerial parts, the percentages of nitrogen using the micro-Kjeldahle method described by Jackson,(1973), phosphorus, colorimetrically as indicated by Cottenie, et al. (1982) and potassium using the Flamephotometer set by Jackson,(1973) were measured.

\section{Experimental design and statistical analysis:}

The layout of the experiment in the two seasons were a randomized complete block design (RCBD) with three replicates Mead et al., (1993), as each replicate consisted of nine seedlings.

The data was then tabulated and subjected to an analysis of variance using the SPSS Program Levesque, (2007), with Duncan's Multiple Range Test (1955) used to confirm the significance level among means of various treatments.

\section{Growth characters:}

\section{RESULTS AND DISCUSSION}

The growth parameters as affected by bio and chemical fertilization treatments are shown in Tab. (1). It was generally noticed that the best means of seedling height and diameter of stem registered significant increments by fertilizing with "Biogien" at the rate of $6.00 \mathrm{~g} / \mathrm{bag}$ or sprayed with "Vive Rose" at $2.00 \mathrm{~g} / \mathrm{l}$. While "Biogien" at 3.00 $\mathrm{g} / \mathrm{bag}$ gave a higher mean number of branches per seedling in the second season compared to control, The root length/seedling was significantly increased with "Rhizobacterien" at the rate of $6.00 \mathrm{~g} / \mathrm{bag}$ and NPK at $4.00 \mathrm{~g} / \mathrm{bag}(14.34 \mathrm{~cm}$ and $11.34 \mathrm{~cm})$ as compared to the untreated seedling $(11.00 \mathrm{~cm})$.

The data indicated that in Tab. (2), the highest means of fresh and dry weights of aerial parts and survival percentage were recorded due to the application of "Biogien" at $6.00 \mathrm{~g} / \mathrm{bag}$ bio-fertilizer addition to "Vive Rose" $2.00 \mathrm{~g} / \mathrm{l}$ in both seasons. On the other hand, fresh and dry roots were significantly increased in seedlings when treated with "Biogien" bio-fertilizer at $3.00 \mathrm{~g} / \mathrm{bag}$ or "Rhizobacterien" $6.00 \mathrm{~g} / \mathrm{bag}$ treatments for the two seasons.

The analyses of variance presented in (Figs. 1, 2, 3, 4 \& 5) showed the effects of different types and doses of bio and chemical fertilization treatments on seedling height/ stem diameter, the relative growth rate of height (RGRH), the relative growth rate of diameter (RGRD), the seedling quality index (QI) and the total dry biomass increment percentage of $P$. halepensis. Untreated seedlings (control) showed a significant decrease (SQ) compared with other treatments. The higher dose of "Biogien" at $6.00 \mathrm{~g} / \mathrm{bag}$ induced capable significant increases in seedling quality index (QI) in both seasons. 
Meanwhile, the relative growth rates of height (RGRH), (RGRD) and total dry biomass increment percentage were greatest in pine seedlings fertilized with "Vive Rose" at $2.00 \mathrm{~g} / \mathrm{l}$, followed by "Rhizobacterien" at $6.00 \mathrm{~g} / \mathrm{seedling}$ for the first and second seasons in comparison with the untreated seedlings and all remaining treatments.

Data indicated that " Biogein" which contained Azotobacter sp., It had the highest vegetative growth rate when compared to the other treatments. According to Gad (2001), Azotobacter chroocooum was capable of N fixation in addition to available phosphorus dissolving and growth promoting gibberellins produced by organisms.

Table 1. Effect of fertilization treatments on some vegetative growth parameters of $P$. halepensis seedlings during 2011 and 2012 seasons.

\begin{tabular}{|c|c|c|c|c|}
\hline & $\begin{array}{c}\text { seedling } \\
\text { height } \\
(\mathrm{cm})\end{array}$ & $\begin{array}{c}\text { Stem diameter } \\
(\mathrm{cm})\end{array}$ & $\begin{array}{l}\text { No. of } \\
\text { Branches/ } \\
\text { Seedling }\end{array}$ & $\begin{array}{l}\text { Root length / } \\
\text { seedling } \\
(\mathbf{c m})\end{array}$ \\
\hline Treatments & \multicolumn{4}{|c|}{ First season: 2011} \\
\hline Control & $8.34 \mathrm{~J}$ & $0.11 \mathrm{H}$ & $2.00 \mathrm{D}$ & $9.00 \mathrm{I}$ \\
\hline Biogien $3.00 \mathrm{~g} / \mathrm{bag}$ & $25.34 \mathrm{DE}$ & $0.23 \mathrm{D}$ & $2.00 \mathrm{D}$ & $12.00 \mathrm{DE}$ \\
\hline Biogien $6.00 \mathrm{~g} / \mathrm{bag}$ & $45.67 \mathrm{~A}$ & $0.34 \mathrm{~A}$ & $3.34 \mathrm{~A}$ & $15.34 \mathrm{~A}$ \\
\hline Rhizobacterien $3.00 \mathrm{~g} / \mathrm{Bag}$ & $22.67 \mathrm{~F}$ & $0.20 \mathrm{E}$ & $2.00 \mathrm{D}$ & $11.00 \mathrm{~F}$ \\
\hline Rhizobacterien $6.00 \mathrm{~g} / \mathrm{bag}$ & $35.67 \mathrm{C}$ & $0.27 \mathrm{C}$ & $2.34 \mathrm{C}$ & $13.00 \mathrm{C}$ \\
\hline Vive Rose $1.00 \mathrm{~g} / \mathrm{l}$ & $27.34 \mathrm{D}$ & $0.23 \mathrm{D}$ & $2.00 \mathrm{D}$ & $12.34 \mathrm{D}$ \\
\hline Vive Rose $2.00 \mathrm{~g} / \mathrm{l}$ & $40.00 \mathrm{~B}$ & $0.31 \mathrm{~B}$ & $3.00 \mathrm{~B}$ & $13.67 \mathrm{~B}$ \\
\hline NPK $1.00 \mathrm{~g} / \mathrm{bag}$ & $15.00 \mathrm{I}$ & $0.17 \mathrm{G}$ & $2.00 \mathrm{D}$ & $10.67 \mathrm{G}$ \\
\hline NPK $2.00 \mathrm{~g} / \mathrm{bag}$ & $20.34 \mathrm{GH}$ & $0.20 \mathrm{EF}$ & $2.00 \mathrm{D}$ & $10.67 \mathrm{G}$ \\
\hline \multirow[t]{2}{*}{ NPK $4.00 \mathrm{~g} / \mathrm{bag}$} & $21.00 \mathrm{FG}$ & $0.21 \mathrm{E}$ & $2.00 \mathrm{D}$ & $10.34 \mathrm{GH}$ \\
\hline & \multicolumn{4}{|c|}{ Second season :2012 } \\
\hline Control & $9.67 \mathrm{~J}$ & $0.21 \mathrm{H}$ & $2.00 \mathrm{D}$ & $11.00 \mathrm{~J}$ \\
\hline Biogien $3.00 \mathrm{~g} / \mathrm{bag}$ & $28.00 \mathrm{DE}$ & $0.45 \mathrm{D}$ & $2.00 \mathrm{D}$ & 13.34 DE \\
\hline Biogien $6.00 \mathrm{~g} / \mathrm{bag}$ & $47.00 \mathrm{~A}$ & $0.61 \mathrm{~A}$ & $3.34 \mathrm{~A}$ & $18.34 \mathrm{~A}$ \\
\hline Rhizobacterien $3.00 \mathrm{~g} / \mathrm{bag}$ & $23.00 \mathrm{~F}$ & $0.43 \mathrm{E}$ & $2.00 \mathrm{D}$ & $12.67 \mathrm{~F}$ \\
\hline Rhizobacterien $6.00 \mathrm{~g} / \mathrm{bag}$ & $36.67 \mathrm{C}$ & $0.54 \mathrm{C}$ & $2.34 \mathrm{C}$ & $14.34 \mathrm{C}$ \\
\hline Vive Rose $1.00 \mathrm{~g} / \mathrm{l}$ & $29.34 \mathrm{D}$ & $0.50 \mathrm{D}$ & $2.00 \mathrm{D}$ & $13.67 \mathrm{D}$ \\
\hline Vive Rose $2.00 \mathrm{~g} / \mathrm{l}$ & $43.34 \mathrm{~B}$ & $0.56 \mathrm{~B}$ & $3.00 \mathrm{~B}$ & $16.84 \mathrm{~B}$ \\
\hline NPK $1.00 \mathrm{~g} / \mathrm{bag}$ & $17.67 \mathrm{I}$ & $0.40 \mathrm{G}$ & $2.00 \mathrm{D}$ & $12.00 \mathrm{G}$ \\
\hline NPK $2.00 \mathrm{~g} / \mathrm{bag}$ & $20.47 \mathrm{GH}$ & $0.42 \mathrm{EF}$ & $2.00 \mathrm{D}$ & $11.67 \mathrm{GH}$ \\
\hline NPK $4.00 \mathrm{~g} / \mathrm{bag}$ & $22.00 \mathrm{G}$ & $0.43 \mathrm{E}$ & $2.00 \mathrm{D}$ & $11.34 \mathrm{HI}$ \\
\hline
\end{tabular}


Table 2. Effect of fertilization treatments on fresh and dry weights of different parts of $P$. halepensis seedlings during 2011 and 2012 seasons.

\begin{tabular}{|c|c|c|c|c|c|}
\hline \multirow[b]{2}{*}{ Treatments } & $\begin{array}{c}\text { Aerial parts } \\
\text { F.W. }(\mathrm{g})\end{array}$ & $\begin{array}{l}\text { Aerial parts } \\
\text { D.W. (g) }\end{array}$ & $\begin{array}{l}\text { Roots F.W. } \\
\text { (g) }\end{array}$ & $\begin{array}{l}\text { Roots D.W. } \\
\text { (g) }\end{array}$ & $\begin{array}{c}\text { Survival } \\
\quad \%\end{array}$ \\
\hline & \multicolumn{5}{|c|}{ First season: 2011} \\
\hline Control & $3.77 \mathrm{~J}$ & $0.93 \mathrm{~J}$ & $0.22 \mathrm{~J}$ & $0.19 \mathrm{~J}$ & 100 \\
\hline Biogien $3.00 \mathrm{~g} / \mathrm{bag}$ & $15.97 \mathrm{E}$ & $5.67 \mathrm{E}$ & $3.25 \mathrm{E}$ & $1.19 \mathrm{E}$ & 100 \\
\hline Biogien $6.00 \mathrm{~g} / \mathrm{bag}$ & $22.82 \mathrm{~A}$ & $10.41 \mathrm{~A}$ & $7.22 \mathrm{~A}$ & $4.17 \mathrm{~A}$ & 100 \\
\hline $\begin{array}{l}\text { Rhizobacterien3.00 } \\
\text { /bag }\end{array}$ & $14.79 \mathrm{~F}$ & $4.68 \mathrm{~F}$ & $2.25 \mathrm{~F}$ & $1.15 \mathrm{~F}$ & 100 \\
\hline $\begin{array}{l}\text { Rhizobacterien6.00 } \\
\text { g/bag }\end{array}$ & $19.77 \mathrm{C}$ & $7.69 \mathrm{C}$ & $4.14 \mathrm{C}$ & $2.09 \mathrm{C}$ & 100 \\
\hline Vive Rose $1.00 \mathrm{~g} / \mathrm{l}$ & $19.57 \mathrm{CD}$ & $7.31 \mathrm{D}$ & $4.11 \mathrm{CD}$ & $2.06 \mathrm{CD}$ & 100 \\
\hline Vive Rose $2.00 \mathrm{~g} / \mathrm{l}$ & $20.57 \mathrm{~B}$ & $9.31 \mathrm{~B}$ & $7.13 \mathrm{~B}$ & $5.11 \mathrm{~B}$ & 100 \\
\hline NPK $1.00 \mathrm{~g} / \mathrm{bag}$ & $7.70 \mathrm{I}$ & $1.34 \mathrm{I}$ & $0.45 \mathrm{I}$ & $0.21 \mathrm{I}$ & 100 \\
\hline NPK $2.00 \mathrm{~g} / \mathrm{bag}$ & $10.92 \mathrm{H}$ & $2.68 \mathrm{H}$ & $0.94 \mathrm{H}$ & $0.36 \mathrm{H}$ & 100 \\
\hline \multirow[t]{2}{*}{ NPK $4.00 \mathrm{~g} / \mathrm{bag}$} & $13.00 \mathrm{G}$ & $3.00 \mathrm{G}$ & $1.00 \mathrm{G}$ & $0.50 \mathrm{G}$ & 100 \\
\hline & \multicolumn{5}{|c|}{ Second season :2012 } \\
\hline Control & $5.81 \mathrm{~J}$ & $3.61 \mathrm{~J}$ & $1.13 \mathrm{~J}$ & $0.24 \mathrm{~J}$ & 100 \\
\hline Biogien $3.00 \mathrm{~g} / \mathrm{bag}$ & $17.39 \mathrm{E}$ & $8.96 \mathrm{E}$ & $3.39 \mathrm{E}$ & $1.54 \mathrm{E}$ & 100 \\
\hline Biogien $6.00 \mathrm{~g} / \mathrm{bag}$ & $25.02 \mathrm{~A}$ & $13.85 \mathrm{~A}$ & $8.22 \mathrm{~A}$ & $5.12 \mathrm{~A}$ & 100 \\
\hline $\begin{array}{l}\text { Rhizobacterien } 3.00 \\
\mathrm{~g} / \mathrm{bag}\end{array}$ & $15.06 \mathrm{~F}$ & $7.84 \mathrm{~F}$ & $2.34 \mathrm{~F}$ & $1.18 \mathrm{~F}$ & 100 \\
\hline $\begin{array}{l}\text { Rhizobacterien6.00 } \\
\text { g/bag }\end{array}$ & $20.80 \mathrm{C}$ & $10.95 \mathrm{C}$ & $6.56 \mathrm{C}$ & $2.93 \mathrm{C}$ & 100 \\
\hline Vive Rose $1.00 \mathrm{~g} / \mathrm{l}$ & $19.61 \mathrm{CD}$ & $9.37 \mathrm{CD}$ & $4.14 \mathrm{CD}$ & $2.88 \mathrm{CD}$ & 100 \\
\hline Vive Rose $2.00 \mathrm{~g} / \mathrm{l}$ & $23.66 \mathrm{~B}$ & $12.34 \mathrm{~B}$ & $7.16 \mathrm{~B}$ & $4.13 \mathrm{~B}$ & 100 \\
\hline NPK $1.00 \mathrm{~g} / \mathrm{bag}$ & $9.75 \mathrm{I}$ & $5.35 \mathrm{I}$ & $0.89 \mathrm{I}$ & $0.39 \mathrm{I}$ & 100 \\
\hline NPK $2.00 \mathrm{~g} / \mathrm{bag}$ & $10.12 \mathrm{H}$ & $6.99 \mathrm{H}$ & $1.29 \mathrm{H}$ & $0.17 \mathrm{H}$ & 100 \\
\hline NPK $4.00 \mathrm{~g} / \mathrm{bag}$ & $12.00 \mathrm{G}$ & $7.52 \mathrm{G}$ & $1.93 \mathrm{G}$ & $0.54 \mathrm{G}$ & 100 \\
\hline
\end{tabular}

Means within a column having the same letters are not significantly different according to Duncan's Multiple Range Test (DMRT) at 5\% level.

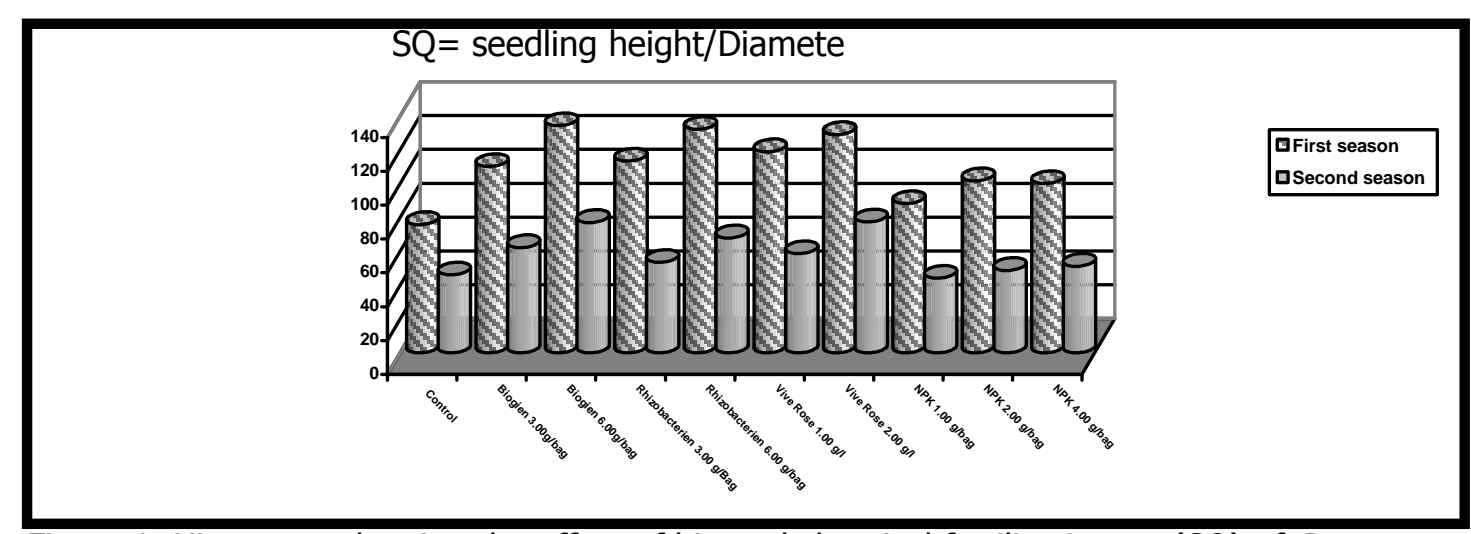

Figure 1. Histogram showing the effect of bio and chemical fertilization on (SQ) of $P$. halepensis. 


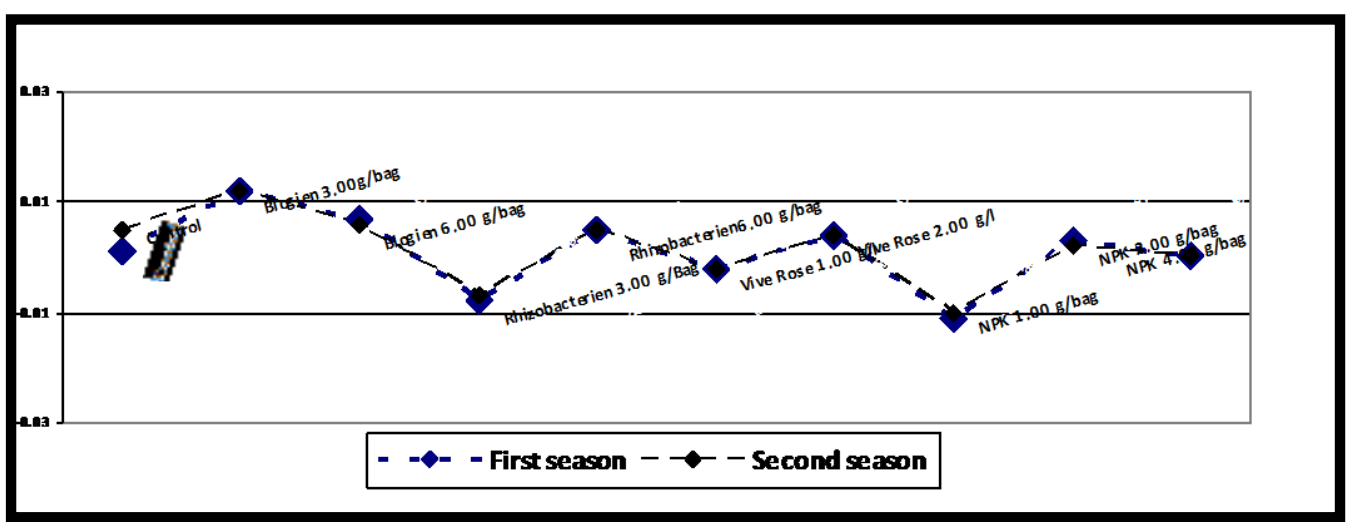

Figure 2. Histogram showing the effect of bio and chemical fertilization on the relative growth rate of height (RGRH) of $P$. halepensis.

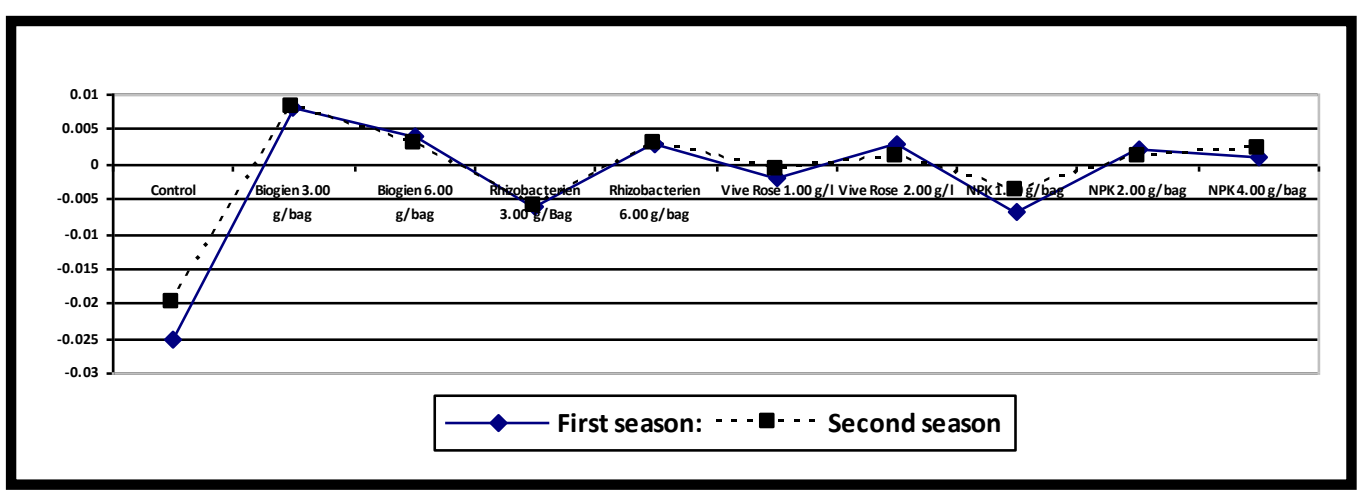

Figure 3. Histogram showing the effect of bio and chemical fertilization on the relative growth rate of diameter (RGRD) of $P$. halepensis.

The seedlings quality index (QI)

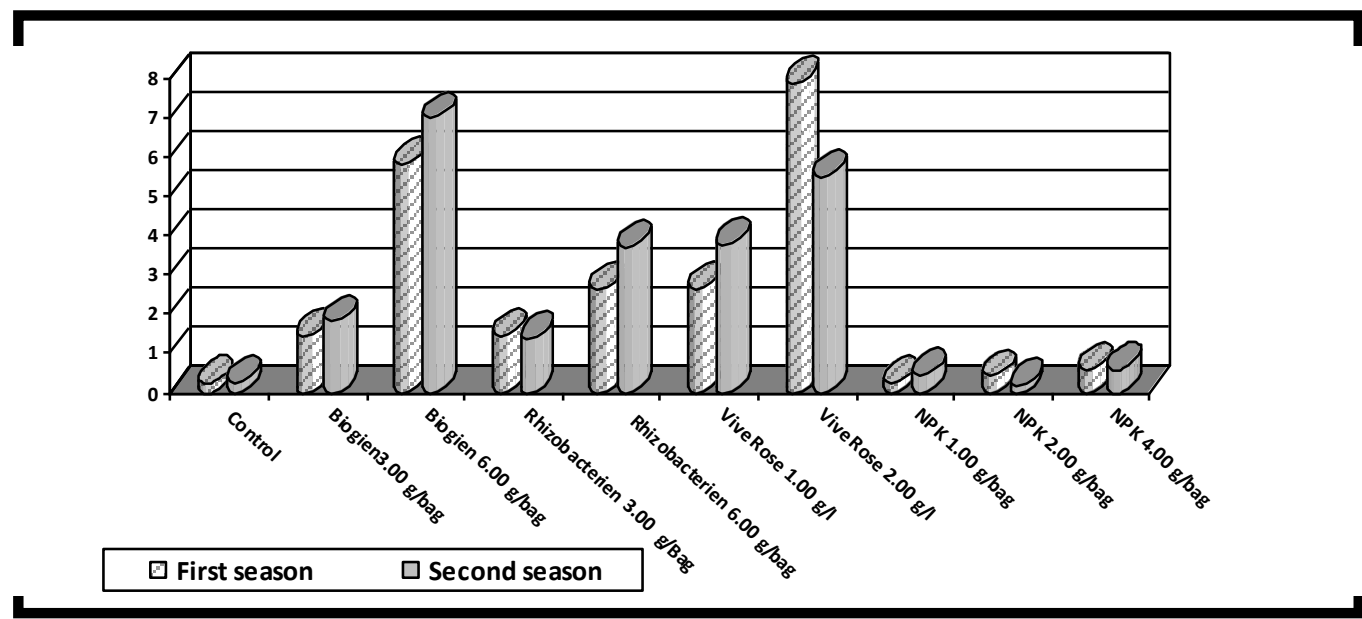

Figure 4. Histogram showing the effect of bio and chemical fertilization on the seedlings quality index (QI) of $P$. halepensis. 
Total dry biomass increment\%

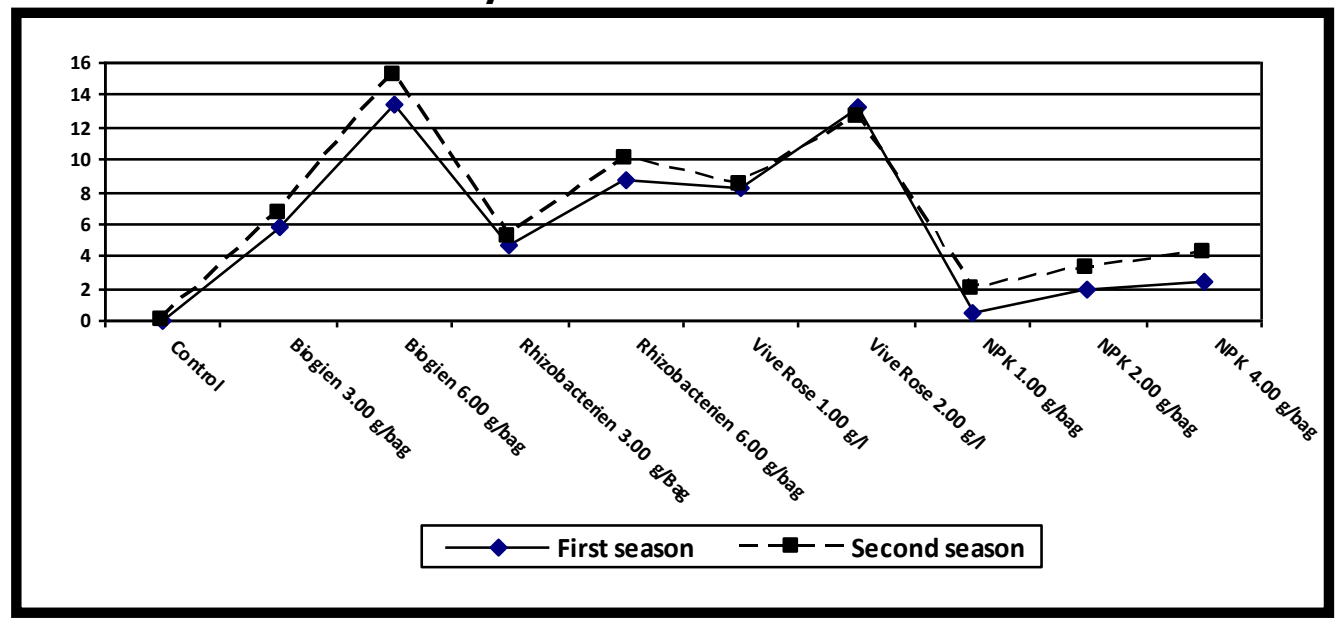

Figure 5 . Histogram showing the effect of bio and chemical fertilization on total dry biomass $\%$ of $P$. halepensis.

\section{Chemical composition:}

\section{Photosynthetic Pigments:}

The highest increases in chlorophyll (a) leaf contents were recorded from seedlings fertilized with "Biogien" at $6.00 \mathrm{~g} / \mathrm{bag}$ and "Vive Rose" at $2.00 \mathrm{~g} / \mathrm{l}$, for the latter (1.55 and $1.14 \mathrm{mg} / \mathrm{g} \mathrm{F.W.)} \mathrm{respectively,} \mathrm{compared} \mathrm{to} 0.09$ (mg/g F.W.) for the control. Meanwhile, treating seedlings with "Rhizobacterien" at $6.00 \mathrm{~g} / \mathrm{bag}$ significantly elevated chlorophyll (b) and caroteniod content in the leaves of pine seedlings compared with control and other treatments. According Tab. (3), mean level of total chlorophyll contents were a significant increment obtained at the dose of NPK 1.00 $\mathrm{g} / \mathrm{bag} 0.15$ (mg/g F.W.) compared to control 0.09 (mg/g F.W.).

According to Tab. (4), it was found that the highest increments in leaf content of $\mathrm{N}$ and P were obtained from seedlings fertilized with "Vive Rose" $(2.00 \mathrm{~g} / \mathrm{l})$. Meanwhile, the highest value of leaf content of $\mathrm{K}$ was induced in seedlings fertilized with "Biogien" $6.00 \mathrm{~g} / \mathrm{bag}$. Data collected reveals few differences in leaf content of total indoles and phenols between all treatments.

These results came in response to the role of $\mathrm{N}$ in chlorophyll and amino acid synthesis, and $\mathrm{P}$ which contributes to regulating the opening and closing of stomata and possibly membrane turgor that affects chlorophyll formation through its radioactive properties. Phosphorus would activate various metabolic processes, and it is involved in energy transfer processes during the building of phospholipids and nucleic acids. Marschner, (1995). Moreover, $\mathrm{P}$ is essential for the biosynthesis of nucleic acids, phospholipids, coenzymes and ATP, which all affect photosynthesis, protein formation, and $\mathrm{N}_{2}$ fixation Buchanan, et al., (2000). As such, seedling development increases when $\mathrm{P}$ addition. 
Table 3. Effect of fertilization treatments on Photosynthetic pigments of $P$. halepensis leaves during 2012 seasons.

\begin{tabular}{|l|c|c|c|c|}
\hline \multicolumn{1}{|c|}{ Treatments } & $\begin{array}{c}\text { Chlorophyll (a) } \\
\text { (mg/g F.W.) }\end{array}$ & $\begin{array}{c}\text { Chlorophyll (b) } \\
\text { (mg/g F.W.) }\end{array}$ & $\begin{array}{l}\text { Chlorophyll (a+b) } \\
\text { (mg/g F.W.) }\end{array}$ & $\begin{array}{c}\text { Carotenoids } \\
\text { (mg/g F.W.) }\end{array}$ \\
\hline Control & $0.09 \mathrm{I}$ & $0.40 \mathrm{~J}$ & $0.09 \mathrm{~J}$ & $0.07 \mathrm{IJ}$ \\
\hline Biogien $3.00 \mathrm{~g} / \mathrm{bag}$ & $0.62 \mathrm{E}$ & $0.28 \mathrm{E}$ & $0.75 \mathrm{E}$ & $0.38 \mathrm{DE}$ \\
\hline Biogien $6.00 \mathrm{~g} / \mathrm{bag}$ & $1.55 \mathrm{~A}$ & $0.88 \mathrm{~A}$ & $1.97 \mathrm{~A}$ & $0.88 \mathrm{~A}$ \\
\hline Rhizobacterien3.00g/bag & $0.28 \mathrm{~F}$ & $0.18 \mathrm{~F}$ & $0.40 \mathrm{~F}$ & $0.20 \mathrm{~F}$ \\
\hline Rhizobacterien6.00g/bag & $0.84 \mathrm{C}$ & $0.51 \mathrm{BC}$ & $1.30 \mathrm{C}$ & $0.62 \mathrm{BC}$ \\
\hline Vive Rose $1.00 \mathrm{~g} / \mathrm{l}$ & $0.76 \mathrm{D}$ & $0.45 \mathrm{CD}$ & $0.93 \mathrm{D}$ & $0.44 \mathrm{D}$ \\
\hline Vive Rose $2.00 \mathrm{~g} / \mathrm{l}$ & $1.14 \mathrm{~B}$ & $0.55 \mathrm{~B}$ & $1.54 \mathrm{~B}$ & $0.77 \mathrm{~B}$ \\
\hline NPK $1.00 \mathrm{~g} / \mathrm{bag}$ & $0.17 \mathrm{H}$ & $0.80 \mathrm{I}$ & $0.15 \mathrm{HI}$ & $0.07 \mathrm{I}$ \\
\hline NPK 2.00 g/bag & $0.24 \mathrm{G}$ & $0.11 \mathrm{GH}$ & $0.20 \mathrm{GH}$ & $0.10 \mathrm{H}$ \\
\hline NPK $4.00 \mathrm{~g} / \mathrm{bag}$ & $0.24 \mathrm{G}$ & $0.14 \mathrm{FG}$ & $0.22 \mathrm{G}$ & $0.18 \mathrm{FG}$ \\
\hline
\end{tabular}

Means within a column having the same letters are not significantly different according to Duncan's

Multiple Range Test (DMRT) at 5\% level.

\section{Nutrient uptake (g/tree):}

The results in (Fig. 6) showed the effect of bio and chemical fertilization treatments at different rates on nutrient uptake. Fertilizing seedlings of pine with "Biogien" at $6.00 \mathrm{~g} / \mathrm{bag}$ and "Vive Rose" at $2.00 \mathrm{~g} / \mathrm{l}$ recorded high significant increments of nutrient uptake as compared to the control or other treatments in the two seasons.

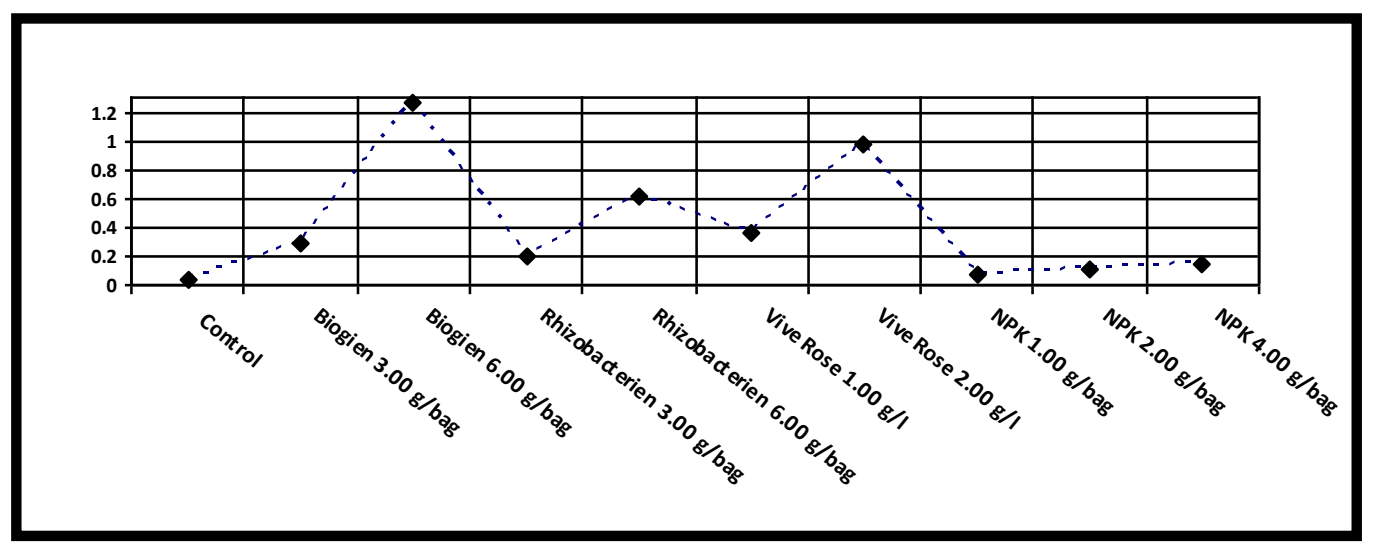

6. Histogram showing the effect of bio and chemical fertilization on nutrient uptake

(g/plant) of $P$. halepensis during 2012 season.

Table 4. Effect of fertilization treatments on chemical composition of $P$. halepensis during 2012 season.

\begin{tabular}{|c|c|c|c|c|c|}
\hline \multirow[b]{2}{*}{ Treatments } & \multirow{2}{*}{$\begin{array}{l}\text { Total indoles } \\
\text { (mg/g F.W.) }\end{array}$} & \multirow{2}{*}{$\begin{array}{c}\text { Total phenols } \\
\text { (mg/g F.W.) }\end{array}$} & \multicolumn{3}{|c|}{ Mineral ions as } \\
\hline & & & N\% & P\% & K\% \\
\hline Control & $0.11 \mathrm{~A}$ & $0.21 \mathrm{~B}$ & $0.15 \mathrm{~F}$ & $0.15 \mathrm{G}$ & $0.80 \mathrm{G}$ \\
\hline Biogien $3.00 \mathrm{~g} / \mathrm{bag}$ & $0.11 \mathrm{~A}$ & $0.22 \mathrm{AB}$ & $0.70 \mathrm{C}$ & $0.95 \mathrm{D}$ & $1.12 \mathrm{C}$ \\
\hline Biogien $6.00 \mathrm{~g} / \mathrm{bag}$ & $0.11 \mathrm{~A}$ & $0.25 \mathrm{~A}$ & $0.84 \mathrm{~B}$ & 3. $79 \mathrm{~B}$ & $1.61 \mathrm{~A}$ \\
\hline Rhizobacterien $3.00 \mathrm{~g} / \mathrm{bag}$ & $0.11 \mathrm{~A}$ & $0.21 \mathrm{~B}$ & $0.80 \mathrm{~B}$ & $0.34 \mathrm{E}$ & $1.06 \mathrm{D}$ \\
\hline Rhizobacterien $6.00 \mathrm{~g} / \mathrm{bag}$ & $0.11 \mathrm{~A}$ & $0.21 \mathrm{~B}$ & $0.84 \mathrm{~B}$ & $2.34 \mathrm{C}$ & $1.24 \mathrm{~B}$ \\
\hline Vive Rose $1.00 \mathrm{~g} / \mathrm{l}$ & $0.12 \mathrm{~A}$ & $0.21 \mathrm{~B}$ & $0.80 \mathrm{~B}$ & $0.95 \mathrm{D}$ & $1.15 \mathrm{C}$ \\
\hline Vive Rose $2.00 \mathrm{~g} / \mathrm{l}$ & $0.12 \mathrm{~A}$ & $0.19 \mathrm{~B}$ & $0.98 \mathrm{~A}$ & $4.09 \mathrm{~A}$ & $1.24 \mathrm{~B}$ \\
\hline NPK $1.00 \mathrm{~g} / \mathrm{bag}$ & $0.09 \mathrm{~B}$ & $0.19 \mathrm{C}$ & $0.20 \mathrm{E}$ & $0.18 \mathrm{~F}$ & $0.90 \mathrm{~F}$ \\
\hline NPK $2.00 \mathrm{~g} / \mathrm{bag}$ & $0.11 \mathrm{~A}$ & $0.12 \mathrm{D}$ & $0.20 \mathrm{E}$ & $0.22 \mathrm{~F}$ & $0.98 \mathrm{E}$ \\
\hline NPK $4.00 \mathrm{~g} / \mathrm{bag}$ & $0.11 \mathrm{~A}$ & $0.10 \mathrm{D}$ & $0.42 \mathrm{D}$ & $0.28 \mathrm{E}$ & $1.15 \mathrm{C}$ \\
\hline
\end{tabular}

Means within a column having the same letters are not significantly different according to Duncan's Multiple Range Test (DMRT) at 5\% leve 


\section{CONCLUSION}

The addition of Biogien at $6.00 \mathrm{~g} /$ bags was most effective in obtaining attractive and high-quality seedlings of $P$. halepensis grown in $14 \mathrm{~cm}$ diameter bags with monthly applications from March to May as a requirement to obtain the best and strongest seedlings, as well as to shorten the time in the nursery in order to reduce the cost of seedlings production and benefit our environment.

\section{REFERENCES}

1. A.O.A.C. 1990. Official Methods of Analysis $\left(15^{\text {th }}\right.$.ed) Association of Official Agricultural Chemists Washington. USA. Pp 62-63,236 and 877-878.

2. Bailey, L.H. 1976. Hortus Third. Macmillan Publishing Co., Inc., 866 Third Avenue, New York, N.Y. 100 22.1290pp.

3. Barbero, M., R. Loisel, P. Quézel, D.M. Richardson and F. Romane, 1998. Pines of the Mediterranean Basin. In: Richardson DM (ed) Ecology and biogeography of Pinus. Cambridge Univ. Press, Cambridge

4. Barriuso, J., Ramos Solano, B., Santamaría, C ., Daza, A ., and F. J. Gutiérrez Mañero. 2008. Effect of inoculation with putative plant growth-promoting rhizobacteria isolated from Pinus spp. on Pinus pinea growth, mycorrhization and rhizosphere microbial communities. J. of Applied Microbiology (2008) Vol. 105 (5): 1298-1309.

5. Bhattacharyya, P., 2012. Plant growth-promoting rhizobacteria (PGPR): emergence in agriculture. World J. Microbiol Biotechnol, 28:1327-1350

6. Buchanan, B. B., W. Grutssen and R.L. Jones. 2000. Biochemistry and molecular biology of plants. American Soc. of Plant Physiologist. USA. 849pp.

7. Cottenie, A., M. Verloo, L. Kiekan, G. Velghe and R. Comerlynck. 1982. Chemical Analysis of plants and Soils. Laboratory of Analytical and Agro chemistry. State Univ., Ghent-Belgium, P. 44-45.

8. Dhindwal A.S., B.P.S. Lather and J. Singh. 1991. Efficacy of seed treatment on germination, seedling emergence and vigor of cotton (Gossypium hirsutum) genotypes, seed Sci. Res., 19:59-61.

9. Dickson, A., A.L. Leaf and J.F. Hosner. 1960. Quality appraisal of white spruce and white pine seedling stock in nurseries. Forest Chrom 36:10-13.

10. Dominguez, J. A., Martin, A., Anriquez, A., A. Albanesi. 2012. The combined effects of Pseudomonas fluorescens and Tuber melanosporum on the quality of $P$. halepensis seedlings. Society of American Foresters, Bethesda, MD, ETATS-UNIS (1955) (Revue) August 2012, Vol. 22, (6) : 429-436. 
11. Duncan, D.B. 1955. Multiple range and multiple F-tests. Biometrices, 11:1-42.

12. Enebak, S.A, G. Wei, and J.W. Kloepper, 1998. Effects of plant growthpromoting rhizobacteria on loblolly and slash pine seedlings. Forest Sci., 44:139-144.

13. Fady, B., 2012. Biogeography of neutral genes and recent evolutionary history of pines in the Mediterranean Basin. Annals of Forest Science, 69:421-428.

14. Farjon, A., 2010. A handbook of the world's conifers. Vol. 2, p.608-784. (Brill, Leiden). $586 \mathrm{pp}$.

15. Gad, W.M., 2001. Physiological studies on Foeniculum vulgare Mill, and Anethum graveolens L. M.Sc. Thesis. Faculty of Agric, Kafr El-Sheikh, Tanta Univ.

16. Iqbal G.M. A., S.M. S. Huda, M. Sujauddin and M.K. Hossain. 2007. Effects of sludge on germination and initial growth performance of Leucaeria leucocephala seedling in the nursry.J.For.Res.,18(3):226-230.

17. Jackson, M. L. 1973. Soil Chemical Analysis. Prentice - Hall of India Private Ltd. M-97,New Delhi, India, 498 pp.

18. Jaiti, F.M., 2007. Effectiveness of arbuscular mycorrhizae (AM) fungi in the protection of date palm (Phoenix dactylifera L.) against bayoud disease. Physiological and Molecular Plant Pathology, 71 (4/6): 166-173.

19. Levesque, R. 2007. SPSS Programming and Data Management: A Guide for SPSS and SAS Users, Fourth Edition (2007), SPSS Inc., Chicago Ill. PDF ISBN 1-56827-390-8 SPSS 15.0 Command Syntax Reference 2006, SPSS Inc., Chicago Ill .

20. Maestre, F.T. and J. Cortina, 2004. Are P. halepensis plantations useful as a restoration tool in semiarid Mediterranean areas? Forest Ecology and Management, 198 (1): 303-317.

21. Marschner, H. 1995. Mineral Nutrition of Higher plants. $2^{\text {nd }}$ Ed., Academic Press, London. pp. 99-101.

22. Mead, R., R.N. Curnow and A.M. Harted. 1993. Statistical Methods in Agriculture and Experimental Biology, $2^{\text {nd }}$ Ed., Chapman \& Hall Ltd., London, $335 \mathrm{pp}$. 
23. Moran, R. 1982. Formula for determination of chlorophyllous pigment extracted with $\mathrm{N}-\mathrm{N}$-dimethyl formamide. Plant physiology., 69:1376-81.

24. Ostos J.C., Lopez - Garrido R., Murillo J.M. and R. Lopez. 2008. Substitution of peat for municipal solid waste- and sewage sludge-based composts in nursery growing media: Effect on growth and nutrition of the native shrub Pistacia lentiscus L. Bioresource Technol., 99 (6): 1793-1800.

25. Probanza, A., G.J.Lucas, P.M.Ruiz, B. Ramos and M.F. Gutiérrez, 2002. Pinus pinea $\mathrm{L}$. seedling growth and bacterial rhizosphere structure after inoculation with PGPR Bacillus (B. licheniformis CECT 5106 and B. pumilus CECT 5105). Applied Soil Ecology, 20 (Suppl 2): 75-84.

26. Ramos, Z.J., R.Orellana, E.B. Allen, 2006. Establishment of Desmoncus orthacanthos Martius (Arecaceae): effect of inoculation with arbuscular mycorrhizae. Revista de Biología Tropical, 54 (1): 65-72.

27. Revillas, J., B.Rodelas, C. Pozo, T.M. Martinez and L. Gonzalez, 2000. Production of B-Group vitamins by two Azotobacter strains with phenolic compounds as sole carbon source under diazotrophicand adiazotrophic conditions. J. Appl. Microbiol, 89:486-493.

28. Rodriguez, H. and R.Fraga, 1999. Phosphate solubilizing bacteria and their role in plant growth promotion. Biotechnol. Adv., 17: 319-339.

29. Saharan, B.S. and V. Nehra, 2011. Plant growth promoting rhizobacteria: a critical review. Life Sci. Med. Res., 21(1),P.30.

30. Thompson, B.E. 1985. Seedling morphological evaluation - what you can tell by looking, (ed) Duryea ML, Evaluating Seedling Quality: Principles, procedures and Predictive Abilities of Major Tests. Forest Res. Laboratory, Oregon State Univ., Corvallis. pp 59-71.

31. Van Loon, L.C., 2007. Plant responses to plant growth-promoting rhizobacteria. European Journal of Plant Pathology, 119(3): 243-254

32. Watfa, R.A., 2009. Effect of soil media, nutrition and mycorrihza fungi on growth and chemical composition of carob and aleppo pine seedlings. M.Sc. Thesis, Fac. of Agric., Cairo Univ., Egypt, 128 pp.

33. Wu, S.C., Z.H.Caob, Z.G.Lib, K.C. Cheunga, and M.H. Wonga, 2005. Effects of biofertilizer containing $\mathrm{N}$-fixer, $\mathrm{P}$ and $\mathrm{K}$ solubilizers and $\mathrm{AM}$ fungi on maize growth: A greenhouse trial. Geoderma, 125: 155-166 


\section{تأثير بعض الأسمده الحيويه و الكيماويه على النمو والتركيب الكيماوي لثتلات الصنوير الحلبي}

\section{هثام عبد السلام غريب ، " حنان محمد أحمد يوسف

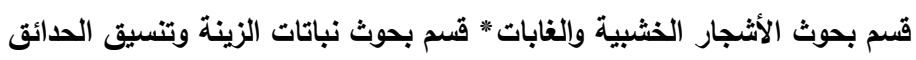

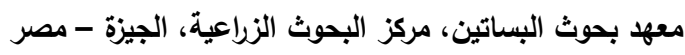

أجري هذا البحث في مشتل قسم بحوث الأشجار الخشبية ـ معهد بحوث البساتين بالجيزة- خلال

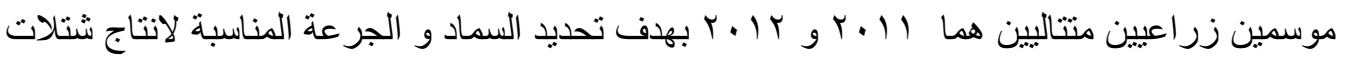
قويه جيدة النمو من الصنوبر الحلبي باستخدام السماد الحيحوي بالبيوجين أو الريزوبكترين) بمعدل

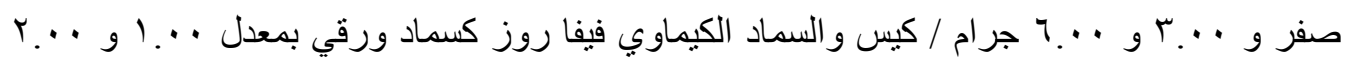

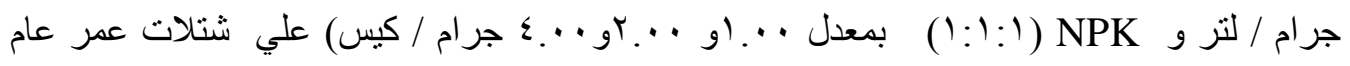

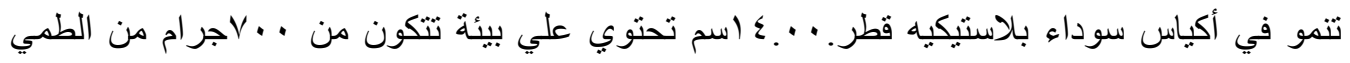
و الرمل بمعدل (1: (1 بالحجم ).

\section{أوضحت نتائج البحث الي ما يلي-:}

ـأعطت معاملة الكنترول أقل زياده في أرتفاع النبات/سمك الساقSQ (مقارنة بباقي المعاملات.

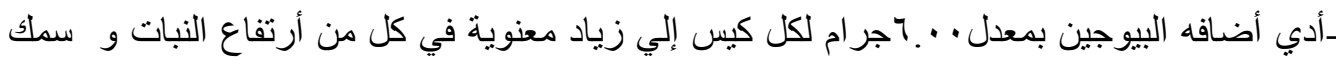
الساق و عدد الأفرع و عدد الأوراق و الطازج والجاف و للأجزاء الخضرية لأوراق و الساق كذللك

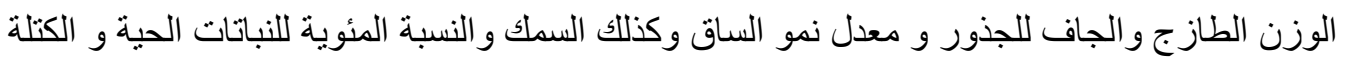
الجافة و امتصاص النيتروجين بمقارنة الكنترول و المعاملات الأخرى في كلا الموسمين.

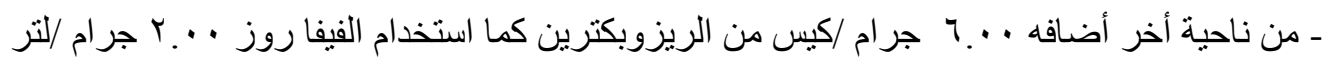
الي زياد طول الجذور ومحتوي الأوراق من كروروفيل ب و الكاروتينويدات و النتروجين و البوتاسيوم

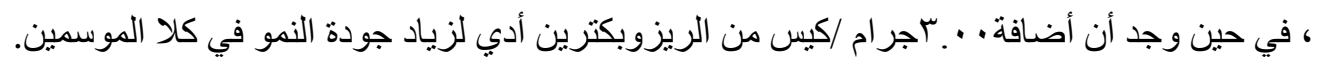

ينصح بتسميد شتلات الصنوبر عند زر اعتها في أكياس بلاستيكية سوداء قطر ها ؛ اسم بمعدل التوصية :

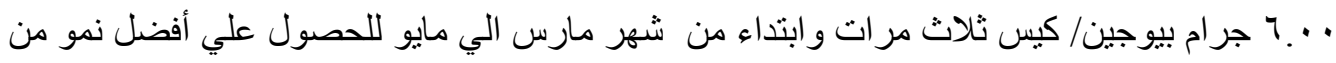
حيث معدل نمو لثلالت مما يساعد في الحصول علي شلات قويه لتقليل فترة بقائها في المشتل مما يقلل مئل من تكاليف الإنتاج بالاضافه إلي أفادته للبيئة. 